\title{
KARAKTERISTIK VULKANISAT KARET PAVING BLOCK DARI LIMBAH KARET SKIM BERBAHAN PENGISI PASIR KUARSA
}

\author{
THE CHARACTERISTIC OF PAVING BLOCK VULCANIZED RUBBER \\ FROM RUBBER SKIM WASTE AND QUARTZ SAND AS THE FILLER \\ Aprilena Tornadez Bondan dan Rahmaniar \\ Balai Riset dan Standardisasi Industri Palembang \\ JI. Perindustrian II No. 12 Sukarami Km. 9 Palembang 30152 \\ e-mail : benaprio@gmail.com
}

Diterima: 26 Mei 2018 ; Direvisi: 1 Juni - 20 Oktober 2018; Disetujui: 26 November 2018

\begin{abstract}
Abstrak
Tujuan penelitian ini adalah mengetahui karakteristik vulkanisat karet paving block yang terbuat dari limbah karet skim dan pasir kuarsa sebagai bahan pengisi, serta memperoleh formulasi barang jadi karet paving block. Karet skim yang digunakan sebagai bahan baku dalam formula sebanyak 100 phr. Rancangan yang digunakan dalam penelitian ini adalah Rancangan Acak Lengkap dengan 2 faktorial yaitu ukuran dan konsentrasi pasir kuarsa. Variasi ukuran partikel pasir kuarsa (A) berturut-turut: $A_{1}=200$ mesh, $A_{2}=400$ mesh. Konsentrasi pasir kuarsa yang digunakan $(B)$ yaitu: $B_{1}=50$ phr, $B_{2}=60 \mathrm{phr}, \mathrm{B}_{3}=70 \mathrm{phr}, \mathrm{B}_{4}=80 \mathrm{phr}$. Parameter yang diamati meliputi karakteristik fisik kompon yaitu tegangan putus, perpanjangan putus, ketahanan ozon dan perubahan volume. Formula terbaik terdapat pada formula 6 (limbah karet skim 100 phr dengan ukuran partikel 400 mesh pasir kuarsa berkonsentrasi 60 phr) dengan nilai tegangan putus $560 \mathrm{~N} / \mathrm{cm}^{3}$, perpanjangan putus $40 \%$, ketahanan ozon no crack dan perubahan volume dalam minyak SAE 40 pada $70^{\circ} \mathrm{C}$ selama 72 jam yaitu $17,97 \%$.
\end{abstract}

Kata Kunci : bahan pengisi, limbah karet skim, pasir kuarsa, paving block

\begin{abstract}
The aim of this research was to know the characteristic of paving block rubber which made from skim rubber waste as the main material, the quartz sand as the filler, and also get its formulation. The raw material used in the research was skim rubber waste 100 phr. This research used Completed Randomized Design (CRD) with 2 factorials. The first factor was the size of quartz sand $(A)$ with the variations, respectively: $A_{1=} 200$ mesh, $A_{2}=400$ mesh. The second factor was quartz sand concentration $(B)$, respectively: $B_{1}=50 \mathrm{phr}, B_{2}=60 \mathrm{phr}, B_{3}=70 \mathrm{phr}, B_{4}=80$ phr. Quality testing for the characteristics of a rubber compound were tensile strength, elongation at break, ozone resistance and volume changing. The quality testing results showed that the value of the physical characteristics of the compound with the best treatment results were the formula 6, which used skim rubber waste 100 phr, quartz sand size 400 mesh with concentration 60 phr. The test result value of tensile strength was $560 \mathrm{~N} / \mathrm{cm}^{3}$, elongation at break was $40 \%$, ozone resistance was no crack, and volume changing in SAE oil 40 at $70^{\circ} \mathrm{C}$ for 72 hours was $17,97 \%$.
\end{abstract}

Keywords: filler, rubber skim waste, quartz sand, paving block

\section{PENDAHULUAN}

Kualitas barang jadi karet sangat ditentukan dari bahan baku, bahan penunjang dan teknologi cara pembuatannya. Kompon karet dibuat dengan cara mencampurkan karet mentah dengan bahan penunjang seperti bahan pelunak, bahan pengisi, bahan pemvulkanisasi, bahan pencepat, bahan penggiat dan bahan-bahan penunjang lainnya. Bahan penunjang yang sangat berpengaruh dalam pembuatan kompon karet yaitu bahan pengisi, dikarenakan bahan ini dalam pembuatan kompon karet digunakan dalam jumlah cukup besar setelah bahan baku.

Bahan pengisi penguat digunakan untuk dapat memperbaiki sifat fisik barang jadi karet (Rattanasom, Saowapark, \& Deeprasertkul, 2007). Jenis dan jumlah 
Aprilena Tornadez

Bondan dan

Rahmaniar
Karakteristik Vulkanisat Karet Paving Block dari Limbah Karet Skim Berbahan Pengisi Pasir Kuarsa bahan pengisi juga menentukan karakteristik produk karet yang diinginkan. Carbon black dan silika sebagai bahan pengisi penguat telah digunakan sebagai bahan utama untuk meningkatkan kegunaan karet, dimana masing-masing memiliki keunggulannya tersendiri di dalam campuran yang dapat mengubah properti mekanis dan dinamis dari vulkanisat (Rattanasom et al., 2007). Penambahan carbon black memang mempengaruhi sifat kompon, viskositas dan kekuatan kompon akan bertambah, namun dikarenakan carbon black diperoleh dari turunan minyak bumi yang tidak terbarukan dan tidak ramah lingkungan maka dilakukan penelitian ini yang menggunakan bahan pengisi bersumber dari non minyak bumi yaitu pasir kuarsa.

Penelitian tentang penggunaan bahan pengisi yang berasal dari non minyak bumi dalam pembuatan barang karet telah banyak dilakukan, dan masing-masing bahan pengisi mempunyai fungsi yang berbeda dalam menghasilkan barang jadi karet. Penelitian bahan pengisi yang berasal dari non minyak bumi diantaranya yang menggunakan pati umbi gadung sebagai substituen carbon black (Susanto \& Prasetya, 2016), rubber-wood fiber (Ratnam, Fazlina, \& Shamsuddin, 2010), kombinasi arang cangkang sawit dengan carbon black N330 (Egwaikhide, A.P., Okieimen, F.E., 2013), dan silika dari pasir kuarsa dan $\mathrm{CaCO}_{3}$ dari kulit kerang (Rahmaniar, Rejo, Priyanto, \& Hamzah, 2014).

Pasir kuarsa dapat digunakan sebagai alternatif bahan pengisi karena pasir kuarsa secara teoritis mengandung unsur kimia yang dapat menambah kekuatan ikatan yang terjadi pada komponen barang jadi karet. Pasir kuarsa mengandung unsur Silika (Si) sebanyak 69,3\%, dan setelah dilakukan sintesis kandungan silika menjadi berkisar antara 83,7\%-96,8\% (Hadi, Munasir, \& Triwikantoro, 2011). Menurut Márquez et al., (2010), pasir kuarsa mengandung kadar $\mathrm{SiO}_{2}$ sebanyak $98,6 \%, \mathrm{Al}_{2} \mathrm{O}_{3} \quad 0,5 \%$, dan $\mathrm{Fe}_{2} \mathrm{O}_{3}$ 0,08\%, dan 97,13\% (Rahmaniar et al, 2015)
Paving block merupakan bahan bangunan yang digunakan sebagai perkerasan permukaan jalan, baik untuk keperluan jalan pelataran parkir kendaraan maupun jalan raya, ataupun untuk keperluan dekoratif seperti pada taman. Paving block yang umum berasal dari bahan bata beton, memiliki kriteria penggunaan yang sesuai dengan masing-masing kelasnya. Syarat mutu paving block diantaranya sifat tampaknya, dimana lantai yang terbentuk sempurna, tidak terdapat retak dan cacat, bagian sudutnya tidak mudah rapuh (Hunggurami et al, 2013).

Penelitian tentang pembuatan paving block pernah dilakukan oleh Ganjian, Jalull, \& Sadeghi-pouya (2015) dengan menggunakan beberapa jenis produk samping dan limbah material, dan hasil yang terbaik adalah yang menggunakan ground granulated blastfurnace slag yaitu produk samping yang terbentuk selama proses produksi besi, digunakan sebagai substituen semen untuk produksi paving block yang ramah lingkungan. Lebih lanjut, pembuatan paving block berbasis ban bekas telah dilakukan oleh Silva, Barbosa, Lintz, \& Jacintho (2015), dimana karet ban digunakan untuk menggantikan pasir alami dalam campuran Concrete dalam pembuatan tactile paving block dengan range substitusi ban karet sebesar $10 \%-50 \%$. Hasil uji yg memuaskan diperoleh pada kuat tekan (compressive strength) dan flexural strength, serta peningkatan ketahanan kikis (abrasion strength). Penelitian lainnya telah dilakukan dengan menggunakan penambahan partikel cangkang kemiri sebagai material penguat komposit dan abu sekam padi, dimana efek penambahan persentase abu sekam padi ke dalam campuran paving block hanya meningkatkan kuat tekan pada saat campuran abu sekam padi sekitar $\pm 8 \%$ dan menurunkan kuat tekan pada saat campuran abu sekam padi lebih dari $8 \%$.

Produksi karet di Indonesia tahun 2017 diproyeksikan mencapai 3,277 juta ton atau naik sekitar 2,98\% dari tahun 2016 (Direktorat Jenderal Perkebunan, 2017). 
Getah karet alam atau lateks merupakan produk dari perkebunan karet. Lateks terdiri dari butiran karet yang terdispersi dalam serum berair, dan proses sentrifugasi menggunakan alat sentrifugal kecepatan tinggi dilakukan untuk mendapatkan 60\% karet dan skim lateks yang mengandung 4-6\% karet (Gopal, Madhu, Radhakrishnan Nair, \& Britto, 2017).

Dalam proses pengolahan lateks alam menjadi lateks pekat dengan metode sentrifugasi, dihasilkan juga limbah yang belum termanfaatkan yaitu skim lateks. Sebagai contoh perhitungan limbah karet skim yang didapat pada perusahaan karet lateks PT. Bumi Rambang Kramajaya pada tahun 2016 adalah sebanyak $0,5 \%$ dari total produksi 200 ton lateks. Lateks skim tersebut memiliki mutu limbah yang jauh melampaui ambang batas, namun masih berpotensi untuk diambil karetnya dan diolah menjadi karet skim, karena masih mengandung karet dengan kadar karet kering (KKK) sekitar 4$8 \%$. Limbah karet skim yang belum dimanfaatkan ini merupakan sumber yang berpeluang untuk dimanfaatkan sebagai bahan pembuatan barang karet seperti paving block. Pada penelitian ini dibuat paving block berbasis karet, yaitu paving block yang dibuat dari kompon karet, diproses dengan sistem cetak vulkanisasi.

Paving block sering mengalami kerusakan yang diakibatkan pengaruh cuaca, hal ini dikarenakan produk tersebut langsung kontak dengan sinar matahari sehingga paving block harus tahan terhadap paparan ozon. Sehubungan dengan hal tersebut di atas maka dilakukan penelitian berbasis karet dengan memanfaatkan limbah karet skim sebagai bahan baku pembuatan paving block karet dan menggunakan bahan pengisi penguat dari pasir kuarsa dengan variasi ukuran partikel.

\section{BAHAN DAN METODA}

\section{Bahan}

Limbah skim, pasir kuarsa ukuran 200 mesh dan 400 mesh, carbon black, kaolin, polysar, minyak jarak, $\mathrm{ZnO}$, asam stearat, cumaron resin, CBS, TMTD, TMQ, Sulfur, $\mathrm{TiO}_{2}$ dan pewarna.

\section{Peralatan}

Sieve shaker, crusher, open mill L $140 \mathrm{~cm}$ D18 cm kapasitas $1 \mathrm{~kg}$, neraca analitis, timbangan Metler p120 kapasitas $1200 \mathrm{~g}$, glassware, timbangan duduk merek Berkel kapasitas $15 \mathrm{~kg}$, cutting scraf besar, alat press, cetakan sheet, gunting dan alat uji laboratorium uji.

\section{Rancangan Percobaan}

Penelitian ini didesain dengan menggunakan Rancangan Acak Lengkap (RAL) dengan 2 faktorial yaitu: variasi ukuran partikel pasir kuarsa (A) dan variasi konsentrasi bahan pengisi pasir kuarsa (B) sebagai berikut :

a. Variasi ukuran partikel pasir kuarsa $(A)$ :

$$
\begin{aligned}
& A_{1}=200 \text { mesh } \\
& A_{2}=400 \text { mesh }
\end{aligned}
$$

b. Konsentrasi pasir kuarsa (B):

$$
\begin{aligned}
& \mathrm{B}_{1}=50 \mathrm{phr} \\
& \mathrm{B}_{2}=60 \mathrm{phr} \\
& \mathrm{B}_{3}=70 \mathrm{phr} \\
& \mathrm{B}_{4}=80 \mathrm{phr}
\end{aligned}
$$

Parameter yang diamati dalam penelitian ini meliputi paramer tegangan putus, perpanjangan putus, ketahanan ozon dan perubahan volume yang disesuaikan dengan SNI Karpet Karet

\section{Tahapan Penelitian \\ Pembuatan bahan pengisi pasir kuarsa}

Pasir kuarsa dihaluskan dengan crusher, dan pasir kuarsa yang sudah hancur kemudian dipisahkan/diayak dengan menggunakan sieve shaker kecepatan 65 rpm selama 20 menit dengan ukuran partikel yang dihasilkan yaitu 200 mesh dan 400 mesh.

\section{Prosedur Pembuatan Kompon Karet Penimbangan}

Bahan yang diperlukan untuk masingmasing formula kompon paving block ditimbang sesuai formula yang terdapat dalam Tabel 1. Jumlah dari setiap bahan di dalam formula kompon dinyatakan dalam phr (berat per seratus karet). 


\begin{tabular}{l|l}
$\begin{array}{l}\text { Aprilena Tornadez } \\
\text { Bondan dan }\end{array}$ & $\begin{array}{l}\text { Karakteristik Vulkanisat Karet Paving Block dari Limbah Karet Skim Berbahan Pengisi Pasir } \\
\text { Rahmaniar }\end{array}$
\end{tabular}

Tabel 1. Formula pembuatan karet paving block

\begin{tabular}{lcccccccc}
\hline \multirow{2}{*}{ Bahan } & \multicolumn{7}{c}{ Formula (phr) } \\
\cline { 2 - 9 } & $\mathbf{1}$ & $\mathbf{2}$ & $\mathbf{3}$ & $\mathbf{4}$ & $\mathbf{5}$ & $\mathbf{6}$ & $\mathbf{7}$ & $\mathbf{8}$ \\
\hline Karet Skim & 100 & 100 & 100 & 100 & 100 & 100 & 100 & 100 \\
$\begin{array}{l}\text { Pasir kuarsa } \\
\text { 200 mesh }\end{array}$ & 50 & 60 & 70 & 80 & - & - & - & - \\
Pasir kuarsa & - & - & - & - & 50 & 60 & 70 & 80 \\
400 mesh & 50 & 50 & 50 & 50 & 50 & 50 & 50 & 50 \\
Kaolin & 20 & 20 & 20 & 20 & 20 & 20 & 20 & 20 \\
Polysar & 2 & 2 & 2 & 2 & 2 & 2 & 2 & 2 \\
Minyak Jarak & 10 & 10 & 10 & 10 & 10 & 10 & 10 & 10 \\
ZnO & 2 & 2 & 2 & 2 & 2 & 2 & 2 & 2 \\
Asam Stearat & 5 & 5 & 5 & 5 & 5 & 5 & 5 & 5 \\
Cumaron resin & 1.9 & 1.9 & 1.9 & 1.9 & 1.9 & 1.9 & 1.9 & 1.9 \\
CBS & 0,5 & 0,5 & 0,5 & 0,5 & 0,5 & 0,5 & 0,5 & 0,5 \\
TMTD & 1,5 & 1,5 & 1,5 & 1,5 & 1,5 & 1,5 & 1,5 & 1,5 \\
TMQ & 10 & 10 & 10 & 10 & 10 & 10 & 10 & 10 \\
Sulfur & & & & & & & &
\end{tabular}

\section{Mixing (pencampuran)}

Proses pencampuran dilakukan dalam gilingan terbuka (open mill), yang telah dibersihkan. Selanjutnya dilakukan proses sebagai berikut karet limbah skim dari pabrik karet dimastikasi selama 1 hingga 10 menit, ditambahkan polysar digiling sampai homogen. dilanjutkan penambahan penggiat/activator, $\mathrm{ZnO}$, asam stearat dan $\mathrm{TMQ}$, digiling selama 5 menit. Pencampuran cumaron resin digiling 5 menit. Bahan pengisi pasir kuarsa (sesuai rancangan percobaan) dan kaolin ditambahkan secara berangsur dan ditambahkan minyak jarak digiling sampai homogen 8 menit. Kemudian ditambahkan TMTD, CBS dan ditambah sulfur dan digiling sampai homogen 2-3 menit, sambil dilakukan penyetelan jarak roll pada cetakan sheet untuk ketebalan kompon $5 \mathrm{~cm}$. Kompon dikeluarkan dari open mill, diletakkan di atas plastik transparan lalu kompon dipotong sesuai dengan ukuran cetakan paving block yang akan dibuat.

\section{HASIL DAN PEMBAHASAN Tegangan putus}

Hasil pengujian tegangan putus tertinggi $710 \mathrm{~N} / \mathrm{cm}^{2}$ dan hasil pengujian tegangan putus terendah $490 \mathrm{~N} / \mathrm{cm}^{2}$. Hasil pengujian tegangan putus dapat dilihat pada Gambar 1. Hasil uji untuk formula 1 sampai dengan formula 8 memenuhi SNI 12-10001989 karpet karet (syarat mutu untuk parameter tegangan putus min $390 \mathrm{~N} / \mathrm{cm}^{2}$ ).

Penambahan pasir kuarsa yang diblending dengan karet skim dalam pembuatan paving block cenderung menaikkan nilai tegangan putus, hal ini dikarenakan pasir kuarsa merupakan bahan pengisi penguat. Silika yang dominan terdapat dalam pasir kuarsa sebagai bahan pengisi kompon mempengaruhi perubahan struktur ikatan silang di dalam komposit karet. Ismail et al. (2005) menyatakan bahwa tegangan putus berkaitan dengan densitas dari cross linking atau sambungan silang yang terdapat dalam metriks suatu polimer. Hal ini diperkuat oleh pernyataan Kanking et al (2012) yang menyatakan bahwa berkurangnya jumlah bahan pengisi di dalam 
penelitiannya yaitu carbon black mengakibatkan penurunan ikatan cross linking serta daya ikat diantara polimer dan matriks pengisi. Dengan demikian, bahan pengisi dapat meningkatkan sifat fisik dan memperbaiki karakteristik barang jadi karet. Bahan pengisi dapat meningkatkan sifat fisik vulkanisat karet, hal ini berhubungan erat dengan luas permukaan, reaktivitas permukaan, ukuran partikel, kelembaban, dan kandungan oksida logam di dalamnya, serta khusus untuk ketahanan kikis akan meningkat seiring dengan semakin besarnya luas permukaan atau semakin kecilnya ukuran partikel bahan pengisi (Egwaikhide, A.P., Okieimen, F.E., 2013).

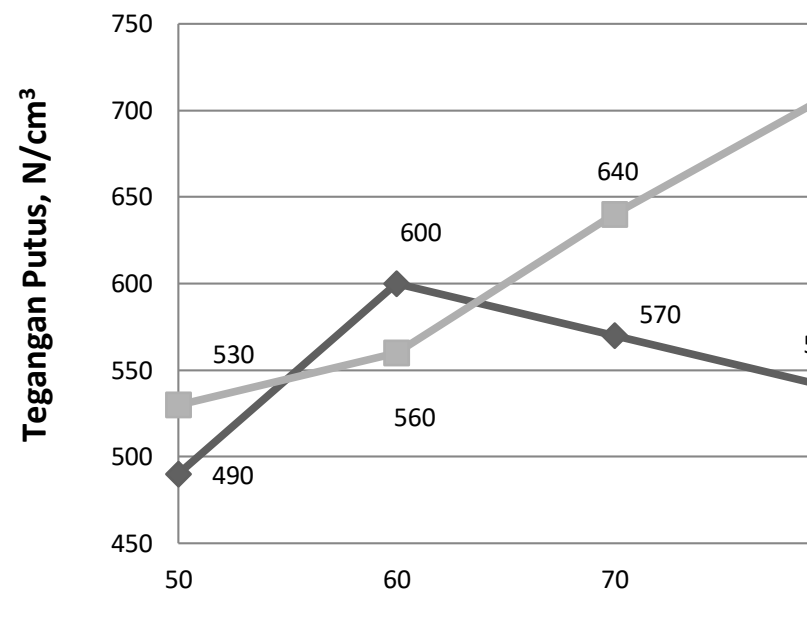

PK dalam Paving Block, phr

$\because$ PK 200 mesh $\quad-$ PK 400 mesh

Gambar 1. Hasil uji tegangan putus barang jadi karet

\section{Perpanjangan putus}

Hasil pengujian perpanjangan putus tertinggi $40 \%$ dan hasil pengujian perpanjangan putus terendah 10\%. Hasil pengujian perpanjangan putus dapat dilihat pada Gambar 2. Hasil uji untuk formula 9 sampai dengan formula 8 memenuhi SNI 12 1000-1989 karpet karet (syarat mutu untuk parameter perpanjangan putus min $50 \%$ ).

Bahan pengisi meningkatkan tegangan putus, perpanjangan putus, dan modulus Young yang mencerminkan efek penguat dari bahan pengisi, hal ini ditandai dengan kekakuan/kekerasan pada karet yang diisi dengan super abrasion furnace black filler (SAF) dan silika (Hassan et al., 2012). Penggunaan pasir kuarsa yang banyak mengandung silika sebagai bahan pengisi penguat dapat mempengaruhi perpanjangan putus seperti halnya tegangan putus. Sebaliknya, kompon karet yang mengandung banyak bahan pengisi yang mudah larut (diluent), skrap, atau karet rekondisi (reclaim), secara signfikan lebih lemah daripada kompon kualitas tinggi, sehingga penggunaannya tidak mempersyaratkan kekuatan tarik yang ketat (Sommer \& Yeoh, 2011). Kenaikan maupun penurunan pada perpanjangan putus dipengaruhi oleh kandungan dari jenis bahan pengisi kompon karet. Nasruddin (2017) menyatakan bahwa jumlah bahan pengisi penambah volume yang berlebihan dapat menurunkan perpanjangan putus, dan sebaliknya penggunaan bahan pengisi penguat pada rasio yang optimal meningkatkan perpanjangan putus.

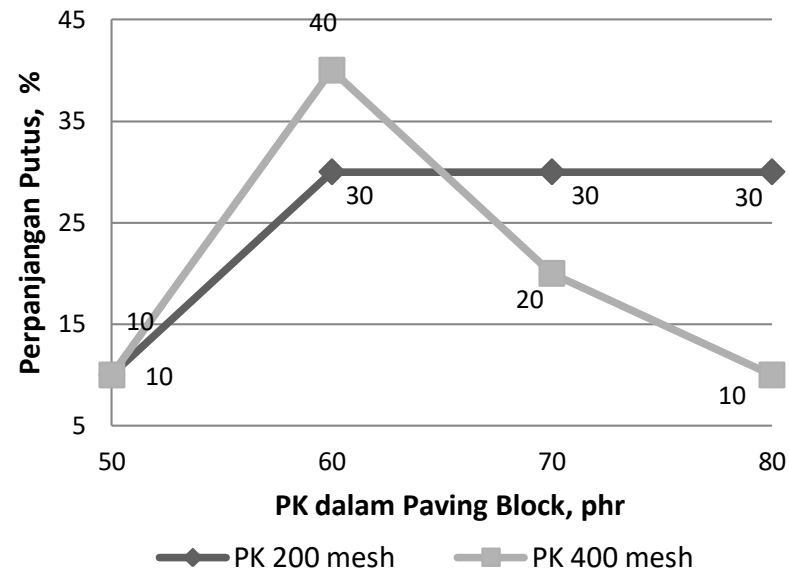

Gambar 2. Hasil uji perpanjangan putus barang jadi karet

\section{Ketahanan Ozon}

Uji ketahanan ozon untuk mengetahui ketahanan retak suatu vulkanisat karet akibat terkena sinar matahari, konsentrasi ozon dalam lingkungan dapat menyebabkan keretakan yang mendalam pada bahan 
Aprilena Tornadez

Bondan dan

Rahmaniar
Karakteristik Vulkanisat Karet Paving Block dari Limbah Karet Skim Berbahan Pengisi Pasir Kuarsa elastomer, sehingga menyebabkan kegagalan komponen barang jadi karet saat digunakan. (Taksapattanakul, Tulyapitak, \& Phinyocheep, 2017), (Fu, Yang, Lvov, Zhang, \& Wang, 2017), (Iwase, Shindo, Kondo, Ohtake, \& Kawahara, 2017),(Piya-areetham, Rempel, \& Prasassarakich, 2014), (Simma, Rempel, \& Prasassarakich, 2009).

Barang jadi karet seperti paving block dapat digunakan di taman bermain atau lainnya berada di udara terbuka sehingga akan terkena sinar matahari. Ketahanan ozon secara visual diamati pada konsentrasi ozon 50 pphm, suhu $40^{\circ} \mathrm{C}$ selama 24 jam menghasilkan no crack/tidak terjadi retak untuk seluruh formula (formula 1 sampai dengan formula 8).

\section{Perubahan volume}

Perubahan volume dilakukan untuk mengetahui paving block mengembang setelah direndam dalam minyak dengan suhu $70^{\circ} \mathrm{C}$ dan waktu 72 jam. Penurunan volume dipengaruhi oleh suhu, waktu dan ukuran partikel bahan pengisi, semakin rendah suhu, semakin lama waktu perendaman dalam minyak, maka perubahan volume akan semakin turun (Holt and McPherson, 1936).

Hasil pengujian perubahan volume tertinggi $19,4 \%$ dan hasil pengujian perubahan volume terendah 4,38\%. Hasil pengujian perubahan volume dapat dilihat pada Gambar 3. Hasil uji perubahan volume tidak menjadi persyaratan di SNI karpet karet maupun SNI tegel karet. (Cam \& Toussaint, 2009), (Samsuri \& Alam, 2017)

Hasil penelitian menunjukkan dengan bertambahnya pasir kuarsa menyebabkan nilai perubahan volume karet cenderung semakin turun, hal ini mengakibatkan sensitif perubahan terhadap oli atau pemuaian terhadap oli.

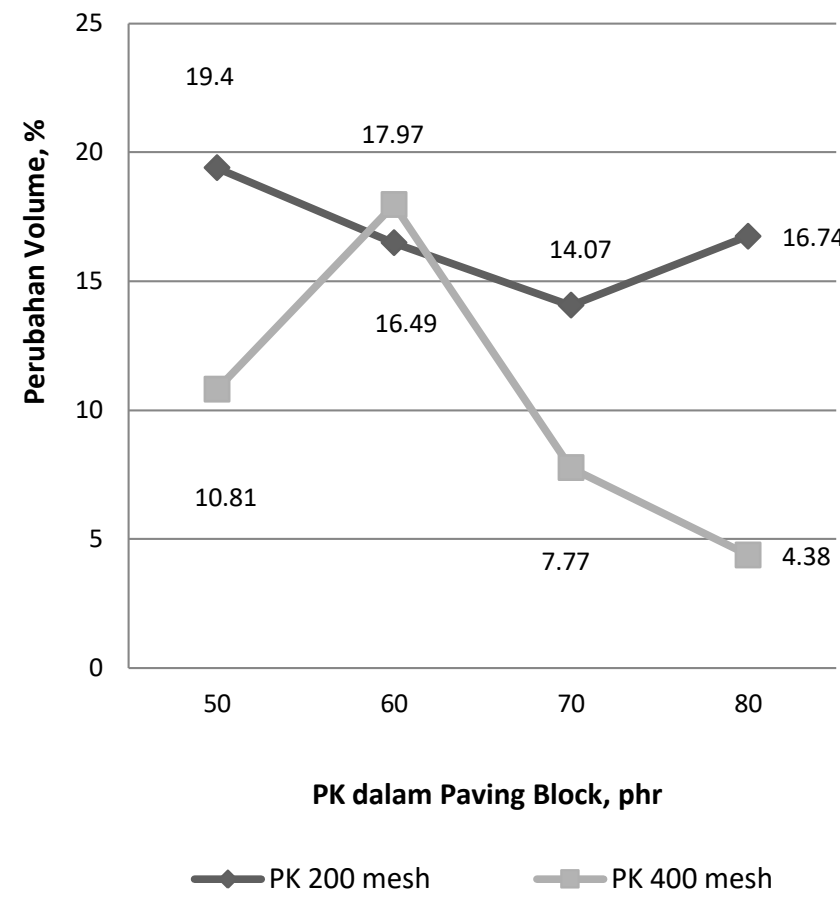

Gambar 3. Hasil uji perubahan volume paving block

\section{KESIMPULAN}

Formula terbaik didapat pada formula 6 (limbah karet skim 100 phr dengan ukuran partikel 400 mesh pasir kuarsa 60 phr) dengan nilai tegangan putus $560 \mathrm{~N} / \mathrm{cm}^{3}$, perpanjangan putus $40 \%$, ketahanan ozon no crack dan perubahan volume in oil SAE 40 pada $70^{\circ} \mathrm{C}$ selama 72 jam yaitu $17,97 \%$.

\section{UCAPAN TERIMAKASIH}

Penulis mengucapkan terima kasih kepada Ibu Nuyah, Bapak Denny Ara dan Bapak Bejo Paranto atas bantuannya dalam melakukan kegiatan praktek lapangan, dan pengujian di laboratorium dalam penelitian ini. 


\section{DAFTAR PUSTAKA}

Direktorat Jenderal Perkebunan, 2017. Statistik Perkebunan Indonesia. Karet 2015-2016.

Cam, J. Le, \& Toussaint, E. (2009). Mechanics of Materials Cyclic volume changes in rubber. Mechanics of Materials, 41(7), 898-901. https://doi.org/10.1016/j.mechmat.2009.02.0 04

Egwaikhide, A.P., Okieimen, F.E., L. . (2013). Rheological and Mechanical Properties of Natural Rubber Compounds Filled with Carbonized Palm Kernel Husk and Carbon Black (N330). Science Journal of Chemistry, 1(5), 50-55. https://doi.org/10.11648/j.sjc.20130105.11

Fu, Y., Yang, C., Lvov, Y. M., Zhang, L., \& Wang, W. (2017). Antioxidant sustained release from carbon nanotubes for preparation of highly aging resistant rubber. Chemical Engineering, 328, 536-545. https://doi.org/10.1016/j.cej.2017.06.142

Ganjian, E., Jalull, G., \& Sadeghi-pouya, H. (2015). Using waste materials and byproducts to produce concrete paving blocks. Construction and Building Materials, 77, 270-275.

https://doi.org/10.1016/j.conbuildmat.2014.1 2.048

Gopal, M., Madhu, G., Radhakrishnan Nair, N., \& Britto, J. (2017). Radiation Treatment of Skim Serum Wastewater From Natural Rubber Latex Centrifuging Units. Environmental Research, Engineering and Management, 73(3), 54-68. https://doi.org/10.5755/j01.erem.73.3.13985

Hadi, S., Munasir, \& Triwikantoro. (2011). Sintesis Silika Berbasis Pasir Alam Bancar menggunakan Metode Kopresipitasi. Jurnal Fisika Dan Aplikasinya, 7(2), 7-10.

Hassan, H. H., Ateia, E., Darwish, N. a., Halim, S. F., \& Abd El-Aziz, a. K. (2012). Effect of filler concentration on the physicomechanical properties of super abrasion furnace black and silica loaded styrene butadiene rubber. Materials and Design, 34, 533-540.

https://doi.org/10.1016/j.matdes.2011.05.005

Iwase, Y., Shindo, T., Kondo, H., Ohtake, Y., \& Kawahara, S. (2017). Ozone degradation of vulcanized isoprene rubber as a function of humidity. Polymer Degradation and Stability, 142, 209-216.

https://doi.org/10.1016/j.polymdegradstab.20 17.06.025
Nasruddin. (2017). Karakteristik Sifat Mekanik Solid Tyre dengan Bahan Pengisi dan Pelunak Berbasis Sumber Daya Alam Lokal. Jurnal Dinamika Penelitian Industri, 28(1), 20-31.

Piya-areetham, P., Rempel, G. L., \& Prasassarakich, P. (2014). Hydrogenated nanosized polyisoprene as a thermal and ozone stabilizer for natural rubber blends. Polymer Degradation and Stability, 102, 112-121. https://doi.org/10.1016/j.polymdegradstab.20 14.01.032

Rahmaniar, Rejo, A., Priyanto, G., \& Hamzah, B. (2014). Karakteristik Kompon Karet dengan Menggunakan Bahan Pewarna dan Bahan Pengisi dari Bahan Alami. In Seminar Nasional Kulit, Karet, dan Plastik ke-3 (pp. 261-274). Yogyakarta: Balai Besar Kulit, Karet dan Plastik.

Ratnam, C. T., Fazlina, R. S., \& Shamsuddin, S. (2010). Mechanical Properties of RubberWood Fiber Filled PVC / ENR Blend ., 5(1), $17-25$.

Rattanasom, N., Saowapark, T., \& Deeprasertkul, C. (2007). Reinforcement of natural rubber with silica/carbon black hybrid filler. Polymer Testing, 26(3), 369-377.

https://doi.org/10.1016/j.polymertesting.2006 .12 .003

Samsuri, A. Bin, \& Alam, S. (2017). Degradation of Natural Rubber and Synthetic Elastomers \$. Reference Module in Materials Science and Materials Engineering. Elsevier Ltd. https://doi.org/10.1016/B978-0-12-8035818.09212-2

Simma, K., Rempel, G. L., \& Prasassarakich, P. (2009). Improving thermal and ozone stability of skim natural rubber by diimide reduction. Polymer Degradation and Stability, 94(11), 1914-1923.

https://doi.org/10.1016/j.polymdegradstab.20 09.08.005

Sommer, J. G., \& Yeoh, O. H. (2011). 10.Tests and Specifications. Engineering with Rubber: How to Design Rubber Components, 365421.

https://doi.org/doi:10.3139/9783446428713.0 11

Susanto, T., \& Prasetya, H. A. (2016). Kajian Penggunaan Pati Umbi Gdung Termodifikasi sebagai Substotuen Carbon Black pada Pembuatan Vulkanisat Karet Alam. Dinamika Penelitian Industri, 27(2), 82-93.

Taksapattanakul, K., Tulyapitak, T., \& 
Aprilena Tornadez

Bondan dan

Rahmaniar
Karakteristik Vulkanisat Karet Paving Block dari Limbah Karet Skim Berbahan Pengisi Pasir Kuarsa
Phinyocheep, P. (2017). The effect of percent hydrogenation and vulcanization system on ozone stability of hydrogenated natural rubber vulcanizates using Raman spectroscopy. Polymer Degradation and
Stability, 141, 58-68.

https://doi.org/10.1016/j.polymdegradstab.20

17.04.006 